\title{
Histo-Morphological Comparison of the Tongue between Grainivorous and Insectivorous Birds
}

\author{
Comparación Histo-Morfológica de la Lengua entre Aves Granívoras e Insectívoras
}

\author{
Nazema S. Abdel-Megeid ${ }^{1}$; Safwat Ali ${ }^{2}$ Mohamed Abdo $^{3.4}$ \& Samy F . Mahmoud ${ }^{5}$
}

\begin{abstract}
ABDEL-MEGEID, N. S.; ALI, S.; ABDO, M. \& MAHMOUD, S. F. Histo-morphological comparison of the tongue between grainivorous and insectivorous birds. Int. J. Morphol., 39(2):592-600, 2021.

SUMMARY: The study aimed to illustrate the influence of feeding habits in the anatomical feature and histological structure as well as some histochemical observations on the tongue of two species of birds which differ in their classification, activity and habitat as; The domestic pigeon, Grainivorous bird, and cattle egret, Insectivorous bird, using light and SEM studies. Results showed that the tongue of two species was differing in size, shape and structure. The tongue of pigeon appeared short and triangular; while in cattle egret was long lanceolate in shape with narrow tapering apex. Dorsal large conical lingual papillae presented between the body and the root of both tongue of the studied birds. They were arranged in form of U-letter in pigeon and in form of wide V-letter in cattle egret. Histologically, both dorsal and ventral lingual surfaces lined with keratinized stratified squamous epithelium, which decreased in the thickness and the degree of keratinization toward the base. The dorsum of the apex of pigeon tongue showed desquamated epithelial cells with filiform papillae, these papillae not observed in the egret $\phi s$ tongue. The tongue of cattle egret contained longitudinal tendinous tissue as intralingual ligament appeared parallel and accompanied with skeletal muscle bundles and attached with entoglossal cartilage. It extended longitudinally from the root to the body of the egret's tongue. The salivary glands presented in the propria submucosal layer of the dorsal surface that extended laterally from apex to the root, while the ventral surface devoid from any glandular structures. The nature of lingual salivary glands showed variations in their histochemical observation to Alcian blue stain and PAS technique. It has been summarized that the morphological and histological variations of both tongues may be correlated to their feeding habits.
\end{abstract}

KEY WORDS: Tongue; Birds; SEM; Histology; feeding habits; Salivary glands.

\section{INTRODUCTION}

The pigeon considered the oldest world's domesticated bird from about ten thousand years ago. They have an importance to humanity, particularly in the times of war also considered important source of meat for people (Blechman, 2007). The cattle egret spread in the hot areas with long expansions. Most people especially the farmers called it Abo-quirdan, meaning "father of ticks", and this name originate from the large number of ticks of birds which spreads in their breeding colonies. The egrets appeared mostly in Egypt, in Delta and Nile Valley, making nests colony close to water bodies on trees and shrubs. They mostly appear together with animals to pick up insects as ticks and flies. The tongue has an important role in mechanism of food in vertebrates especially in birds. Therefore, this mechanism is very important to detect the adaptation and perseverance of vertebrates to their environmental habits (Darwish, 2012).

Variations in morphology in shape and size of the tongue allowing its functions as a special tool for obtaining, manipulation, swallowing and processing food. Many authors has been studied the morphology of the tongue in vertebrates (Zweers, 1982). According to their lifestyle, birds have different feeding habits, with differences corresponding to the shape of their beak and tongues. Most bird's lives in different environment such as the air, the land and the water, many authors illustrated that the shape and structure of the tongue differs according to the type of food and method of food intake (Jackowiak et al., 2011; Al-Zahaby \& Elsheikh,

\footnotetext{
${ }^{1}$ Cytology and Histology Department, Faculty of Veterinary Medicine, University of Sadat City, Sadat City 32897, Egypt.

${ }^{2}$ Department of Anatomy and Embryology, Faculty of Veterinary Medicine, Minia University, Egypt.

${ }^{3}$ Department of Animal Histology and Anatomy, School of Veterinary Medicine, Badr University in Cairo (BUC). Egypt.

${ }^{4}$ Department of Anatomy and Embryology, Faculty of Veterinary Medicine, University of Sadat City, Sadat City 32897, Egypt.

${ }^{5}$ Department of Biotechnology, College of Science, Taif University, P.O. Box 11099, Taif 21944, Saudi Arabia.
} 
2014). The tongues of birds are adapted for manipulation, collection, and swallowing of foods. Studies of morphological and functional aspects of different species of birds indicated a close relation to the histological structure of the tongue with their feeding habits (Emura et al., 2009a; Guimares et al., 2009; Abou-Zaid \& Al-Jalaud, 2010; Mahmoud et al., 2017).

The structure of mucosa of the tongue, type and distribution of lingual papillae and the degrees of keratinization of the lingual epitheliumin relation to feeding habits were described by many authors as white tailed eagle (Jackowiak \& Godynicki, 2005), cormorant (Jackowiak et al., 2006), ostrich (Jackowiak \& Ludwig, 2008), peregrine falcon and common kestrel (Emura et al., 2008), spot-billed duck (Emura, 2009a), three species of herons (Emura, 2009b), woodpecker (Emura et al.), common quail (Parchami et al., 2010), domestic pigeon (Parchami \& Dehkordi, 2011), red jungle fowl (Kadhim et al., 2014), chukar partridge (Erdogan et al., 2012), Muscovy duck (Igwebuike \& Anagor, 2013), white-throated kingfisher and common buzzard (ElBeltagy, 2013), Black Francolin (Kadhim et al.), the common kingfisher (Al-Zahaby \& Elsheikh), southern lapwing (Erdogan \& Perez, 2015). From the previous observations, there are a correlation between shape, structure of the tongue and nature of food, also the mechanism of food intake and bird's habits.

This study aimed to illustrate the influence of the nature of food and the methods of feeding intake on the macroscopic and microscopical observations of the tongue between two different birds in feeding habits and type of food as the domestic pigeon (Grainivorous) and the egret (Insectivorous), using light microscopy and scanning electron microscope studies, to interpret the present result to other previous studies in relation to avian feeding habits.

\section{MATERIAL AND METHOD}

Eight tongues of both pigeons and egrets were investigated. The birds were captured from El-Menofiya Governorate, Egypt. The birds were observed prior to being sacrificed, to ensure their health condition and for any clinical signs indicating infection. Only apparently healthy birds were selected for this study; the tongues were quickly dissected from the mouth cavity and processed as follows: For scanning electron microscopy (SEM), different parts of tongue were rapidly fixed overnight in modified glutraldehyde solutions (2\% paraformaldehyde and $2.5 \%$ glutraldehyde containing $0.1 \mathrm{M}$ phosphate-buffered solution, $\mathrm{pH} 7.4$ ) at $4{ }^{\circ} \mathrm{C}$. After rinsing in $0.1 \mathrm{M}$ phosphate buffer (pH
7.4) the samples were post fixed in phosphate-buffered solutions ( $\mathrm{pH} \mathrm{7.4)} \mathrm{of} 1 \%$ osmium tetroxide at $4{ }^{\circ} \mathrm{C}$ for 2 hours. These specimens were then washed in $0.1 \mathrm{M}$. phosphate buffer solution several times before treating with $3 \mathrm{~N}$ hydrochloric acid for $20 \mathrm{~min}$ at $60{ }^{\circ} \mathrm{C}$ to remove extra cellular mucus from the lingual surface. The specimens were then washed in phosphate buffer solution and dehydrated in ascending graded ethanol series to the critical-point of drying and gold coated. The specimens were then examined in a JEOL-JSM 5300 Scanning Electron Microscope at the faculty of Medicine, Tanta University (Hayat, 2000).

For light microscopy, different parts of the tongues were rapidly set in $10 \%$ neutral-buffered formalin solution for at least 48 hours, then dehydrated in ascending ethanolxylene and embedded in paraffin wax. $5 \mu \mathrm{m}$ serial sections were cut transversely and stained with haematoxylin and eosin, Masson's trichrome stain for detection of the demonstration of collagen fibers, Weigert's elastic tissue stain for demonstration of elastic fibers and some special histochemical stains as Alcian blue stain and Periodic acid Schiff techniques for detection the nature of lingual salivary glands secretion (Bancroft \& Gamble, 2002).

\section{RESULTS}

Gross morphology. Neither the shape nor the dimensions of the tongue of the birds showed specific-sex differences. The dorsum of the tongue of Pigeon and Egret were distinguished into three parts; apex, body and root. It is distinguished dorsally from its anterior half by a clear median groove, except on its apical region and some parts along its posterior part. This groove was dividing the lingual apex and the body of the tongue into two symmetrical halves. The tongue of adult domestic pigeon appeared triangular, small with narrow anterior part and wide fleshy posterior part (Fig. 1). While it was very long, lanceolate with narrow and tapering apex in cattle egret (Fig. 2). Conical papillae were arranged symmetrically in the marginal region between the body and the root, these papillae take the form of the letter $(\mathrm{U})$ in pigeon while take $(\mathrm{V})$ letter in egret. The lateral papillae were larger and thicker than the middle one in both pigeon and egret (Figs. 1 and 2).

Scanning Electron Microscope Studies (SEM): SEM in the domestic pigeon revealed that, deep sulcus dividing the apex and body of the tongue into two symmetrical halves (Fig. 3A). The surface of the dorsum of the anterior part of the tongue was covered by a large number of irregular scaley protrusions of the deciduous epithelial growths. (Fig. 3B). Filliform papillae were compactly distributed along the 


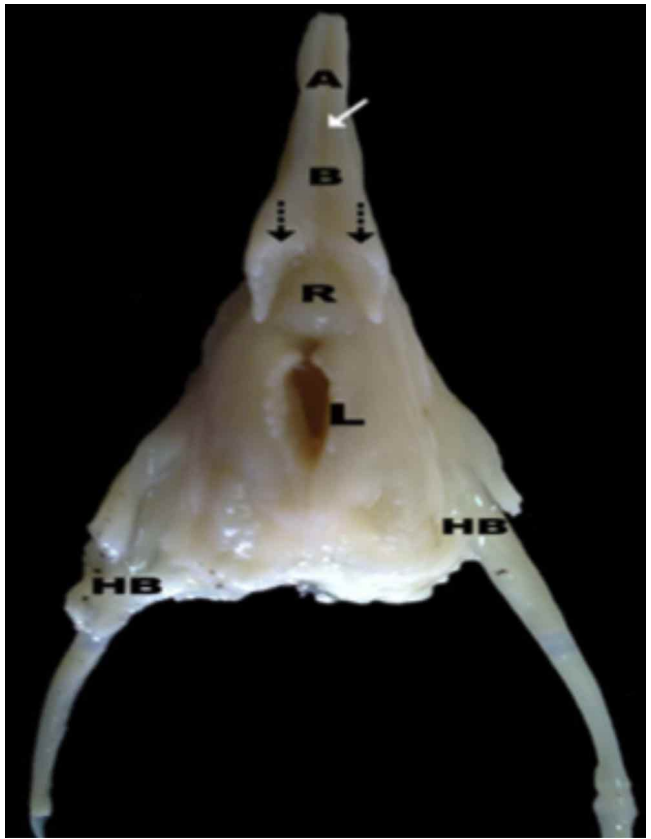

Fig. 1. Photograph of the pigeon tongue showing parts of the tongue, lingual apex (A), body (B) and the root $(\mathrm{R})$, the median groove (white arrow). Note, the arrangement of the - U- shaped conical papillae (black dotted arrow). Laryngeal mound (L), hyoid bone (HB).

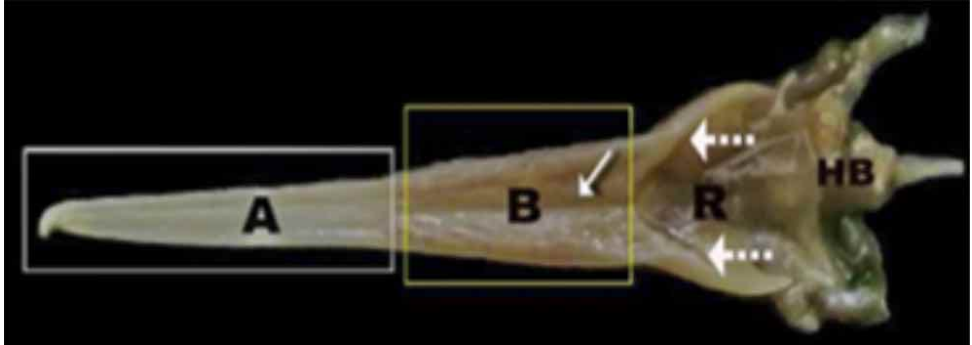

Fig. 2. Photograph of the dorsal surface of the tongue of the egret showing parts of the tongue, apex (A); body (B); root (R), entoglossal bone (EB), the giant conical papillae (white spotted arrow), and the median sulcus in the caudal part of the body (white arrow), hyoid bone (HB).

lingual body. They were long, slender with broad tip. The filliform papillae were backwardly directed and situated around the median sulcus (Fig. 3C), in the margin between the body and the base of the tongue, small sized conical papillae were observed and they were numerous arranged asymmetrically in the form of a letter (U). The lateral papillae were larger and thicker than the middle one. The dorsum of the base of tongue showed smooth appearance with no densely packed desquamated cells and no lingual papillae are observed (Fig. 3D).

While in the cattle egret, SEM revealed that, the dorsum of the anterior lingual part from the apex to the end of the body of the tongue was somewhat appeared smooth, devoid of any lingual papillae. The epithelium
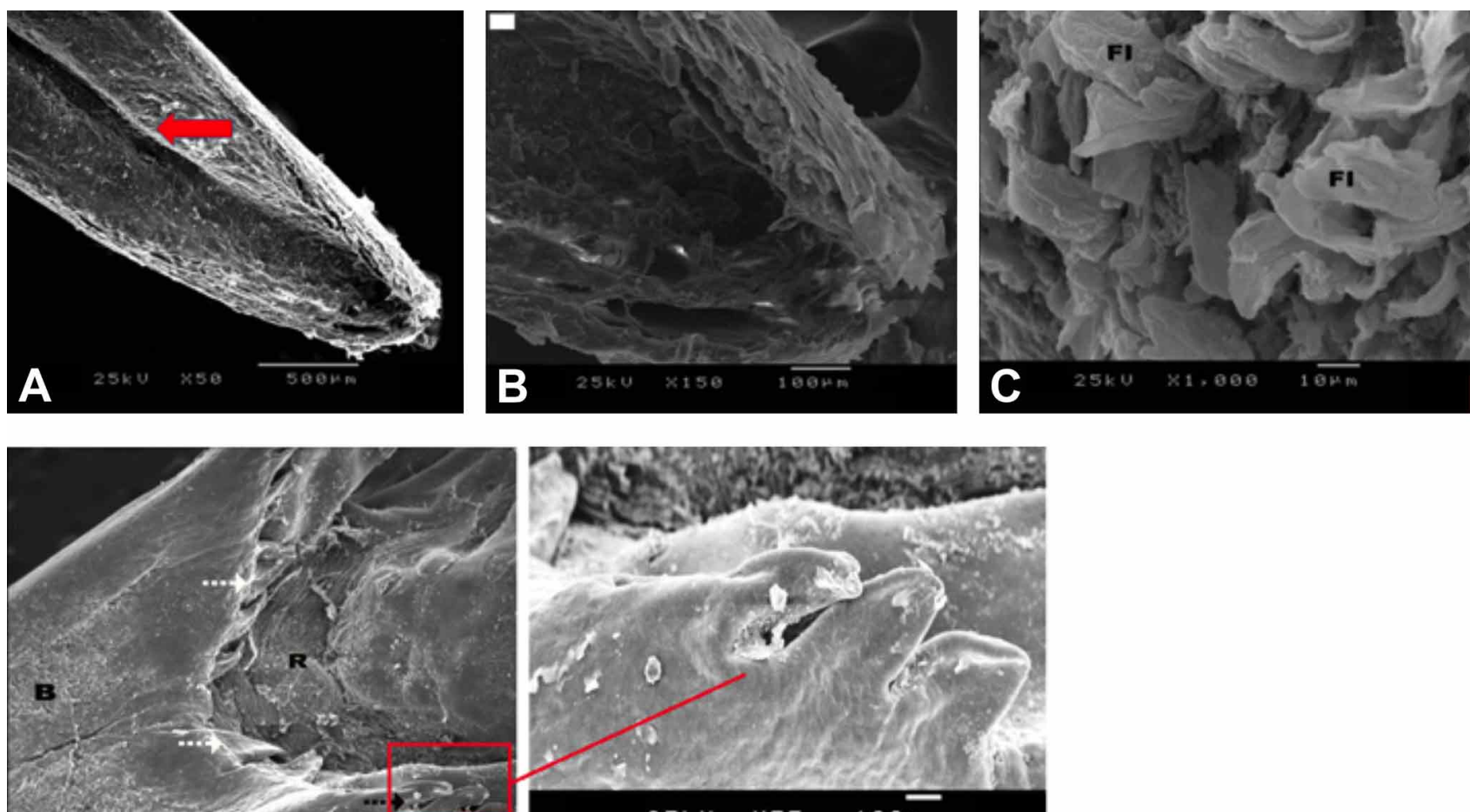

D

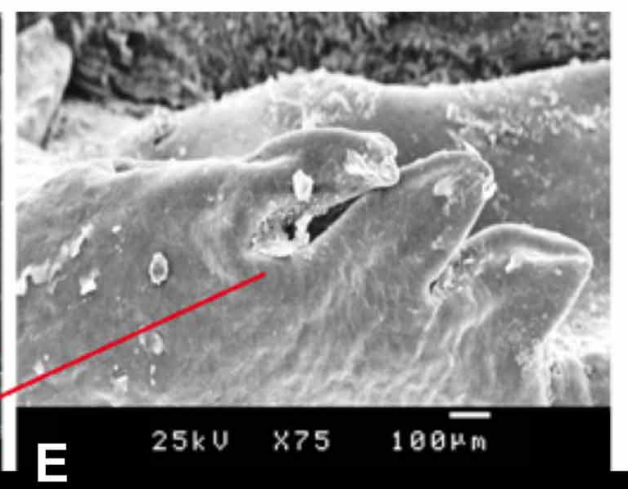

Fig. 3. Scanning electron micrograph. of the dorsal surface of the pigeon tongue showing. a, Median groove dividing the tongue into two symmetrical halves (arrow). b, the irregular scalyprotrusions and scales in tip of tongue (arrow). c, the filiform papillae (FI) backwardly directed in the body of tongue. $d$, the arrangement of the lingual conical papillae (black arrow ), note the lateral papillae is more thicker than the middle one (dark spotted arrow). e, higher magnification of Fig. (d) showing large lateral conical papilaae with some scaley protrusions on its surface. 
of this region was slightly undulated. Scanty number of irregular scales was observed on the dorsal surface of the lingual apex with characteristic median groove dividing the tongue into two symmetrical halves (Fig. 4A). Longitudinal pellicae were observed at both sides of the anterior part of the lingual body. These pellicae arranged at almost regular intervals, in addition few scales were frequently arranged over the surface of the pellicae (Fig. 4B). On the caudal part of the lingual body, longitudinal and transverse ridges or pellicae also noticed at both sides of the tongue around the median sulcus with widely distributed tiny scales on their surfaces (Fig. 4C). Giant papillae were located in a transverse row at the end of the lingual body which completed by caudal continuation of giant conical papillae, larger and thicker than the middle one. (Fig. 4D). The middle papillae were domeshaped in outline and some scales frequently observed on their dorsal surface. Well-developed micro ridges were widely distributed on the cell surface of the dorsum of the giant conical papillae (Fig. 4E). The lateral lingual papillae was larger inclined backwardly toward the pharynx (Fig.
4G). The surface of root also devoid of lingual papillae showing widely distributed rounded openings of the caudal lingual salivary glands; the openings of the salivary glands were surrounded by capsule (Fig. 4F).

Light Microscope Studies. Histologically, the lining epithelium of the dorsal surface of the tongue in both pigeon and egret consisted of a stratified squamous keratinized epithelium. The keratinized layer was thicker in the ventral and lateral surfaces especially in the tip of the lingual apex (Figs. 5A and 6A). The dorsal surface was thicker than the ventral surface. The base of this epithelium was uneven, being thrown into shallow and narrow folds. The cells of both the basal and the deep intermediate layers were rounded or elliptical in shape and have large, central and spherical nuclei. From the deep intermediate layer to the superficial layer, the cells and the nuclei gradually flattened and desquamating cells were detectable on the upper surface (Figs. 5B and 6B). On the superficial layer of the dorsal surface of the body of the pigeon tongue, there were distinct
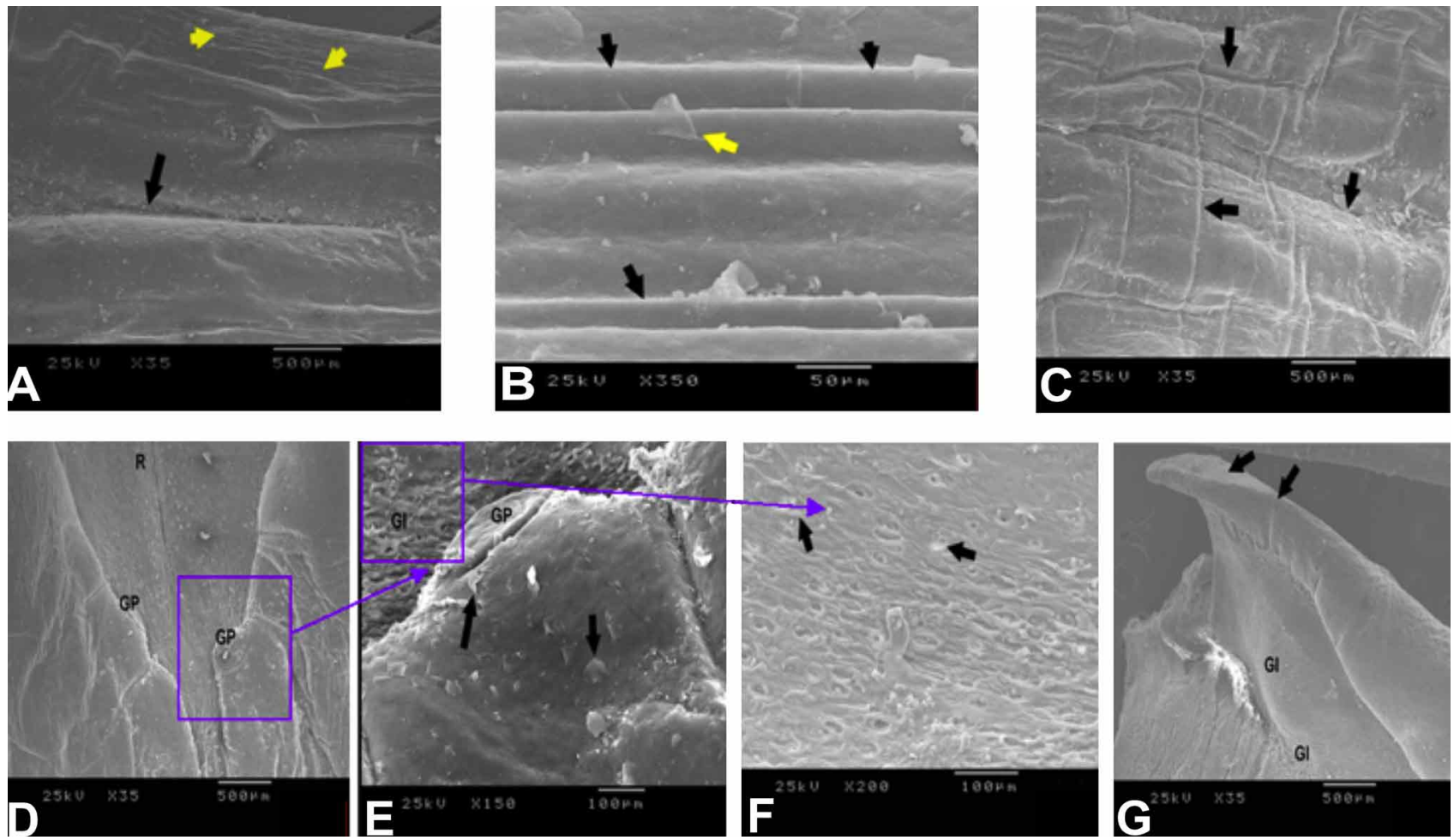

Fig. 4. Scanning electron micrograph of the dorsal surface of the cattle egret tongue showing. A, longitudinal groove on the anterior part of the lingual body (dark arrow) and ridges on the lateral lingual surface (yellow arrow). B, Longitudinal pellicae arranged at almost regular intervals, with few scales on their surface (black arrow) on the lingual body. C, longitudinal and transverse ridges (pellicae) (black arrow) with compactly distributed scales and the central lingual sulcus. D, the widely distributed openings of the caudal lingual salivary glands. Note, the giant conical papillae. (GP). on the root of the tongue. E, Higher magnification of Fig.(D) showing the giant papillae (GP) of the egret tongue. Note that the giant papillae are dome-shape in outline with characteristic scales on their surface. (Black arrow). F, opening of salivary glands on the root of egret tongue. $\mathrm{G}$, the giant conical lateral papillae directed caudally toward the pharynx (black arrows) and opening of salivary glands (Gl) on the root). 

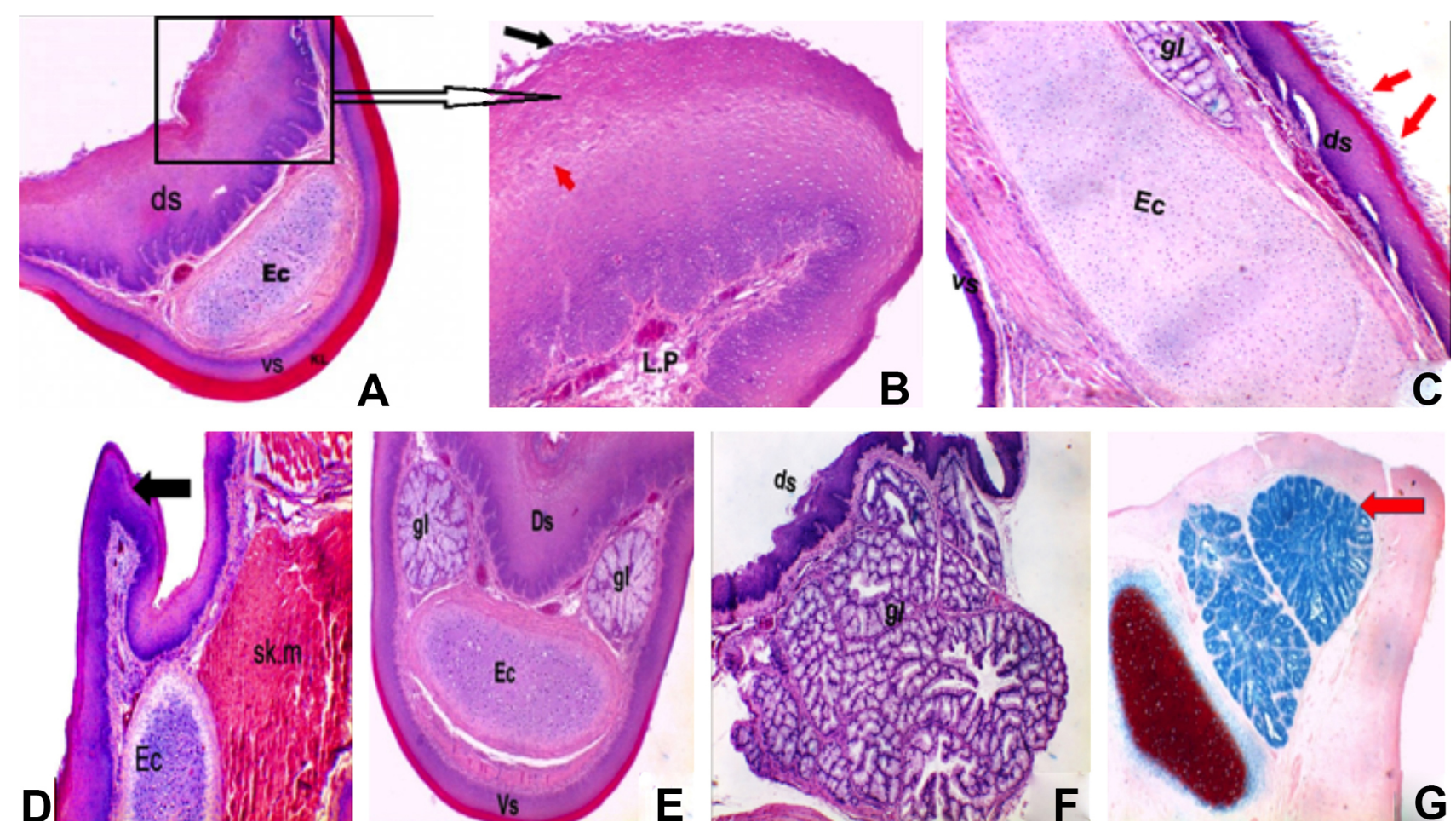

Fig. 5. Photomicrophotographs of the pigeon tongue showing. A, the thick dorsal surface (ds) and thin ventral surface (vs) with thick keratinized layer( KL) and the entoglossal cartilage (EC) on the lingual apex of tongue, $\mathrm{H} \& \mathrm{E} \times 40$. B, desquamation of the epithelial surface, lamina propria ( L.P) $\mathrm{H} \& \mathrm{E} \times 100$. C, superficial desquamated epithelial cell which represented as filliform papillae (black arrows) on body of tongue. D, showing, the conical papillae, entoglossal cartilage and the attached skeletal muscle on the posterior part. $(\mathrm{H} \& \mathrm{E} \times 40)$. E, lingual mucus gland $(\mathrm{gl})$, thick dorsal surface, thin keratinized ventral surface, entoglossal cartilage $(\mathrm{Ec}) \mathrm{H} \& \mathrm{E} \times 40$. $\mathrm{F}$, root of tongue with caudal mucus salivary gland $(\mathrm{gl})$ and non keratinized dorsal surface. $\mathrm{G}$, positive alcianophilic substance in lingual salivary gland. $(\mathrm{AB} \mathrm{PH} 2,5 \times 100)$.

protrusions of the desquamated epithelial cells which may represented as filliform papillae (Fig. 5C). The keratinization was also highly developed at the giant conical papilla which separating the body of the tongue from the base fixed part which inclined backwardly toward the pharynx (Figs. 5D and 6D). Gustatory lingual papillae were not found in the epithelium covering the tongue in both studied birds. The lamina propria consisted of loose connective tissue containing collagen fibers, thin elastic fibers and numerous blood vessels (Fig. 6C). There were muscles in the lamina propria of the dorsal surface of the tongue. The muscles were arranged thin and striated in the form of circular in the lingual apex, but oriented in the form of circular and longitudinal in different direction in the body and root of the tongue.

The skeleton of the tongue in pigeon was supported by cartilage hyoid apparatus revealed on entoglossal bone as skeletal element of the tongue which extending from the lingual root to lingual apex (Figs. 5C, D, E). While in cattle egret, an intra-lingual tendon was longitudinal fibrous structure parallel and accompanied with skeletal muscle fibers and attached with entoglossal cartilage (Figs. 6E and F). The lingual salivary glands of pigeons and egrets were located in the lamina propria of the second half of the free part of the tongue till the root of the tongue. Therefore, the lingual salivary glands of both studied birds could be divided into two types: Anterior lingual glands at the anterior part of the tongue and posterior salivary glands at the root of the tongue, both of them were typically mucous gland in the pigeon. The mucous secretory units composed of tall columnar cells with extensive vesicular cytoplasm. These glands were surrounded by connective tissue capsule with septa dividing the gland into lobules) (Figs. 5F and 6G). They open on the epithelial surface through minute pores (Fig. 6F).

The secretory cells of the lingual salivary glands of the pigeons, contained large amount of acid mucopolysaccharide substances that showed strong positive reaction to alcian blue stain while give negative reaction to PAS techniques (Fig. 5G). The ventral surface of the tongue is devoid of any glandular structure. while in the egret, the anterior one appeared serous adenomere while mixed (sero mucoid) in the posterior one. The alcianophilic substances appeared to be increased in amount in the cytoplasm of secretory cells of the posterior salivary lingual glands and showed strong positive reaction to alcian blue stain (Fig. 6H). 


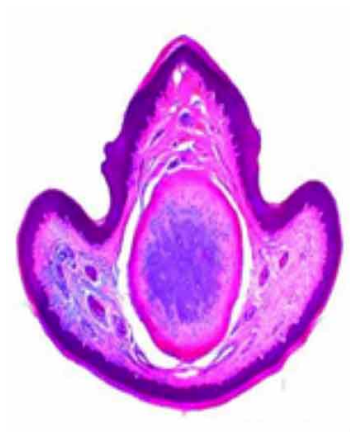

A
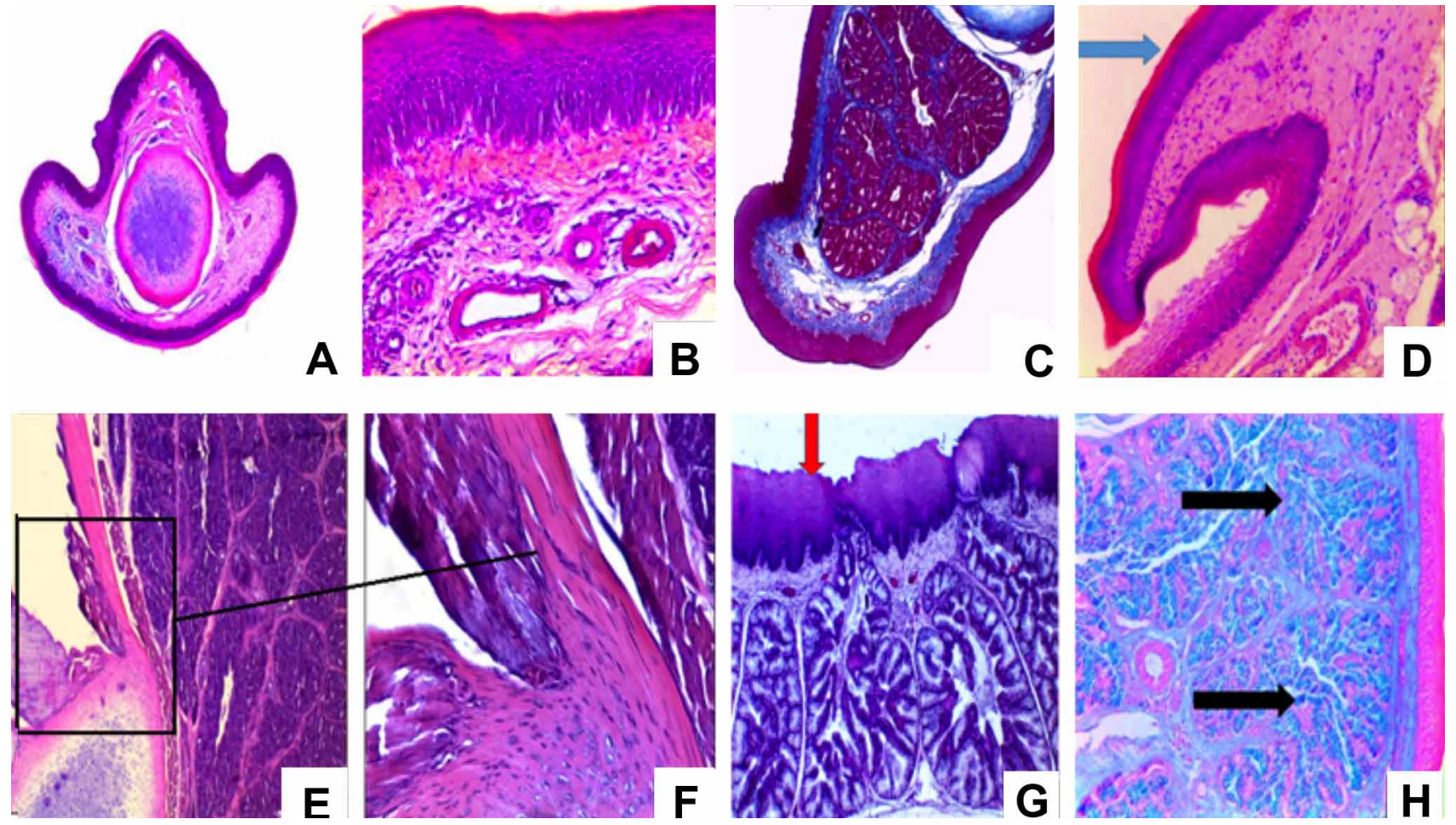

Fig. 6. Photomicrograph of the egret tongue. A, the dorsal and ventral surface in the lingual apex. B, distribution of elastic fibers around the blood vessels. C, collagen fibers in lamina propria and surrounding the gland. D, the highly keratinized lingual conical papillae. E, entglossal cartilage and the origin of the intra lingual tendon (red arrow). F, A higher magnification of Fig. (E) showing the entoglossal tendon attached to the lingual skeletal muscle. G, lingual salivary glands opening in the epithelium of the dorsal surface. $\mathrm{H}$, positive alcian blue and PAS lingual salivary gland. $(\mathrm{AB}, \mathrm{PH} 2.5+\mathrm{PAS}$ combination $\times 100)$.

\section{DISCUSSION}

Gross morphology. The present study was carried out to clarify the structural features of the tongue between two birds living in different environments feeding habits and food sources. The structural characteristics of components of the avian digestive tract are largely determined by the kind of diet consumed by the particular species. There are different types of adaptation of the bird's tongue, such as for accumulating food, handling food and swallowing (Jackowiak \& Godynicki).

Previous studies in the avian tongue revealed that the morphology, structure of the epithelium linguae, supportive components also papillae localization are thoroughly related with the nature of food, mode of feeding also the different habitats (Whittow, 2000). Results achieved from the current study revealed that the tongue of domestic pigeon is a characteristic triangular organ with three distinct anatomical parts: apex, body and root. These morphological features resemble those of common quail (Parchami et al.), domestic chicken (Homberger \& Meyers, 1989) and chuker partridge
(Erdogan, 2012). While the long cattle egret's tongue of the current study prolongs to fill almost the cavity of the lower beak and is terminating with sharp, tapered apex. This offers suitable eating possibilities for searching for small food items such as insects in rubbish dumps and bodies of animals (AlZahaby, 2016). These description of the tongue is same similar to that of Chukar partridge (Erdogan et al.), which also feeds on insects in the ground pastures.

Data found from this study also showed that definite median sulcus divides the apex and body of the tongue into two similar halves. These results resemble of those described on the tongue of white tailed eagle, grey heron (Abou-Zaid \& Al-Jalaud) and domestic goose (Jackowiak et al., 2011), however it is lacking on the tongue of chickens and ostrich, besides these features show the adaptation of the tongue to aid swallowing grains as whole pieces in the esophagus (Iwasaki, 2002). Also the current study showed that a main row of great conical papillae are situated symmetrically in the form of the letter $U$ in the marginal region between the 
lingual body and the lingual root. These results are similar to those the documented by Parchami et al. and Parchami \& Dehkordi (2011), in common quail and domestic pigeon. In the chucker partridge and common quail, the root of the tongue have conical papillae with the pointed apex directed caudally arranged in the letter V; behind this row there is an additional row composed of laterally sited large papillae (Erdogan et al.). While in the Middendroffs bean goose and domestic goose there are giant conical papillae located between the body and basal region also on the lateral sides of the anterior region of the tongue. There are lingual hairy papillae densely distributed and small numbers of large cylindrical papillae are arranged between these lingual hairs (Iwasaki et al., 1997), that is not noted in the present study. On the other hand, Pasand et al. (2010) reported the giant conical papillae in ostrich were not detected between the lingual body and root. Occurrence of these lingual papillae has been reflected to be related to specific feeding habits of birds, the conical papillae found in the lingual body was helping in the transfer of swallowed food towards the esophagus and preventing its regurgitation.

Scanning Electron Microscope. The ultrastructural observations in the present study revealed that the pigeon tongue has large numbers of backwardly directed scales on the lingual apex and slender filiform papillae with a broad tip on the rest of the lingual body. Moreover, no fungiform papillae presents between the filiform papillae as mentioned in grey heron (Abou-Zaid \& Al-Jalaud), domestic chick (ElBeltagy) also King fisher (Al-Zahaby \& Elsheikh). This result was similar to some species of birds but the shape of the processes differing from each other, they were needle shaped processes in woodpecker (Emura et al.), lamellar shaped in pigeon (Parchami \& Dehkordo, 2011), carpetshaped in the peregrine falcon and common kestrel (Emura et al.), thread-shaped in the owl species (Emura et al., 2009a), spine-like in the penguins (Kobayashi et al., 1998), acicular processes in the European Magpie and the Common Raven (Erdogan \& Alan, 2012), also many processes can be observed in the black kite (Emura).

The microridges present on the root in the pigeon and egret may develop the transport of food otherwise, seed or insects through the surface of the tongue and perform as sites for preservation of the mucous produced by the lingual salivary glands located on the base of tongue. The distribution of the apical scales and in the present investigation, giant papillae were arranged at the final part of the lingual body in both specimens, being big and conical in shape in the pigeon and small with rounded profile in the egret. These much larger giant papillae in the pigeon may help in pushing the dry seeds into the pharynx. However, these papillae are smaller in the egret because the food consists of worms and insects, which are soft enough for smooth swallowing. These giant papillae so-called "lingual spikes" by Kooloos (1986). The distribution pattern of these papillae was the same in the Mallard (Kooloos), in the chicken (Iwasaki \& Kobayashi, 1986), in the little tern (Iwasaki), in duck (Abdalla, 1994), in Middendroff's Bean Goose (Iwasaki et al.). The presence of these giant papillae in these different species of birds may be related to their phylogenic origin.

Light microscope observation. In this current study, we observed that mucosa of the dorsum of the lingual apex (tip) is lined with a thick keratinized stratified squamous epithelium only on the lateral and ventral surface, whereas the lingual body and root are lined with non- keratinized stratified squamous epithelium, this result is similar to that described through (Jackowiak \& Godynicki) in white tailed eagle and by Parchami \& Dehkordi (2011) in domestic pigeon. Contrary to reports in chucker partridge, the dorsal surface of its tongue was lined with thick keratinized stratified squamous epithelium Erdogan et al., whereas in the ostrich, the dorsal and ventral surfaces of the tongue were lined by non-keratinized stratified squamous epithelium (Jackowiak \& Ludwig).

The changes in the degree of keratinization of the lingual epithelium between different species look to be related to the differences in habitat. These differences clearly appear in chickens' live in habitat, being much drier than that of the water fowls like Middendroff's bean goose, domestic ducks and the little tern. In birds, the amount of keratinization of lingual epithelium looks to be a certain degree, to reflect differences in their life style (Erdogan \& Perez). In most birds, anterior tip of the tongue is directly contact with food and may avert injuries during feeding. In this study, the lingual epithelium of pigeon is thick keratinized and has solid plates, as it is exposed to solid grains and seeds during feeding. Lateral edges and ventral surface of the tongue may be exposed to hard grains and seeds, during handling and when stored in the buccal cavity. Therefore, epithelium covered with a thick keratinized layer. This interpretation agreed with Al-Nefely (2015) in laughing dove. Observations of the present study showed that the lamina propria is dense irregular connective tissue, which contains adipose cells and numerous blood vessels. This connective tissue supported by the strong layer of striated muscle fibers, which are oriented in longitudinal and circular direction in the body and base of the tongue. In addition, the tongue contains hyaline cartilage, which extends from the lingual apex to the lingual root and surrounded by lingual muscle fibers. These observations are similar to that of Pasand et al. in male ostrich and Parcham \& Dehkordi (2011) in domestic pigeon. Homberger and Meyers stated that in birds, the tongue maintained by unpaired paraglossae 
extending through the lingual tip and articulates caudally with the basihyoid apparatus.

In the present study, the tongue of domestic pigeon and cattle egret supported by elements of the hyoid apparatus. It spreads ventrally to the apex of the tongue as a narrow point, paraglossal apex, then becomes flat and thicker in the tongue's body called the corpus paraglossale. This last cartilage remains caudally and bifurcates in the tongue's root as two paraglossalis caudalis ending on the each side of the trachea as a hyoid bone. In cattle egret showing different structure not observed in the pigeon hyoid apparatus, which is the paraglossal apparatus enveloped with a definite perichondrium consisted of fibrous connective tissue and striated muscle fibers, assisting for moving of the tongue out of the mouth cavity. Likewise, Erdogan et al. stated that the hyaline paraglossal cartilage supporting the chukar partridge's tongue, which extends in the lingual root, body and apex. Igwebuike \& Anagor also accepted the presence of the paraglossal skeleton and associated striated muscle fibers of the tongue in Muscovy duck. In brief, the tongue apparatus of the egret displays certain anatomical and microscopical structures that are distinctive to this bird species. This may be an adjustment to the method of food intake, the type of food, lifestyles and bird's habitat (AlZahaby).

In this study, we showed that the lingual glands are simply branched tubulo alveolar glands; they did not appear in the lingual apex but appeared in the lingual body, which open on the epithelial surface through minute pores. It increased in numbers through the basal region of the tongue. The lingual salivary glands prolonged from the apex of the tongue to both sides of the laryngeal cleft in the white-eared bulbul (Parchami \& Dehkordi, 2013). The lingual salivary glands are absent in the fundamental tongue of cormorants (Jackowiak et al., 2006). In this study, the lingual salivary gland in both pigeon and egret take positive reaction to alcian blue stain while negative to PAS technique as observed on the tongue of the little egret. In contrast, in red jungle fowl, Zebra finch, Black Francolin and common kestrel which their salivary gland take strong positive to PAS reaction which indicated to their content of neutral mucin (El-Beltagy; Kadhim et al.). Saliva aids in softening ingested food to facilitate swallowing, keep the mucous membrane of the upper digestive tract protected from injures of hard grains (Parchami \& Dehkordi, 2011).

In conclusion, results of the present study revealed that the tongue of both studied birds were different from each other in their shape; electron microscope observations and histological analysis identified their differences in feeding habit and habitat.

\section{ACKNOWLEDGMENTS}

We appreciate and thank Taif University for the financial support for Taif University Researchers Supporting Project (TURSP-2020/138), Taif University, Taif, Saudi Arabia.

ABDEL-MEGEID, N. S.; ALI, S.; ABDO, M. \& MAHMOUD, S. F. Comparación histo-morfológica de la lengua entre aves granívoras e insectívoras. Int. J. Morphol., 39(2):592-600, 2021.

RESUMEN: La investigación tuvo como objetivo ilustrar mediante estudios de luz y SEM, la influencia de los hábitos alimentarios en la característica anatómica y estructura histológica, así como algunas observaciones histoquímicas en la lengua de dos especies de aves, que se diferencian en su clasificación, actividad y hábitat, como es la paloma doméstica, ave granívora y la garcilla bueyera, ave insectívora. De acuerdo a los resultados la lengua de las dos especies difería en tamaño, forma y estructura. La lengua de las palomas tenía una forma corta y triangular; mientras que en la garceta bueyera era de forma larga lanceolada con ápice estrecho y agusado. Grandes papilas dorsales linguales cónicas entre el cuerpo y la raíz de ambas lenguas estaban dispuestos en forma de letra $\mathrm{U}$ en paloma y en forma de letra $\mathrm{V}$ ancha en garza bueyera. Histológicamente, las superficies linguales dorsal y ventral estaban revestidas con epitelio escamoso estratificado queratinizado que disminuía en el grosor y el grado de queratinización hacia la base. El dorso del ápice de la lengua de la paloma mostró células epiteliales descamadas, estas papilas no se observaron en la lengua de la garceta. Se observó tejido tendinoso longitudinal en la lengua de la garceta bueyera, debido a que el ligamento intralingual aparecía en forma paralela y acompañado de haces de músculo esquelético y adherido con cartílago entogloso. Se extendía longitudinalmente entre la raíz hasta el cuerpo de la lengua de la garceta. Las glándulas salivales de la lengua estaban incrustadas en la capa submucosa propia de la superficie dorsal que se extendía lateralmente desde el ápice hasta la raíz, mientras que la superficie ventral carecía de estructuras glandulares. En las glándulas salivales linguales se observaron variaciones histoquímicas a la tinción con azul de Alcian y la técnica PAS. En conclusión, las variaciones morfológicas e histológicas de ambas lenguas pueden estar correlacionadas con sus hábitos alimentarios.

PALABRAS CLAVE: Lengua; Aves; SEM; Histología; Hábitos alimentarios; Glándulas salivales.

\section{REFERENCES}

Abdalla, K. E. A comparative anatomical study of the tongue in chicken pigeon and duck. Egypt. J. Anat., 17(4):221-37, 1994.

Abou-Zaid, D. F. A \& Al-Jalaud, N. A. The structural adaptations of the lingual apparatus of the grey heron, ardea cinerea. Egypt. J. Exp. Biol. (Zool.), 6(2):307-17, 2010 
Al-Nefely, F. A. Functional morphology of the tongue and lingual epithelium of the laughing dove in relation to feeding habit. Int. J. Res. Stud. Biosci., 3(2):14-9, 2015.

Al-Zahaby, S. A. \& Elsheikh, E. H. Ultramorphological and histological studies on the tongue of the common kingfisher in relation to its feeding habit. J. Basic Appl. Zool., 67(3):91-9, 2014.

Al-Zahaby, S. A. Light and scanning electron microscopic features of the tongue in cattle egret. Microsc. Res. Tech., 79(7):595-603, 2016.

Bancroft, J. D. \& Gamble, M. Theory and Practice of Histological Techniques. $5^{\text {th }}$ ed. London, Churchill Livingston, 2002.

Blechman, A. Pigeons. The Fascinating Saga of the World's Most Revered and Reviled Bird. St Lucia, Queensland, University of Queensland Press, 2007.

Darwish, S. T. Comparative histological and ultrastructural study of the tongue in Ptyodactylus guttatus and Stenodactylus petrii (Lacertilia, Gekkonidae). J. Am. Sci., 8(2):603-12, 2012.

El-Beltagy, A. M. Comparative studies on the tongue of white throated king fisher and common Bazard. Egypt. Acad. J. Biol. Sci., 4(1):1-14, 2013.

Emura, S. SEM studies on the lingual papillae and their connective tissue cores of the black kite (Milvus migrans) (in Japanese). Med. Biol., 152:43-7, 2008

Emura, S.; Okumura, T. \& Chen, H. Scanning electron microscopic study of the tongue in the oriental scops owl (Otusscops). Okajimas Folia Anat. Jpn., 86(1):1-6, 2009a.

Emura, S.; Okumura, T. \& Chen, H. Scanning electron microscopic study of the tongue in the peregrine falcon and common kestrel. Okajimas Folia Anat. Jpn., 85(1):11-5, 2008.

Emura, S.; Okumura, T. \& Chen, H. Scanning electron microscopic study of the tongue in the Japanese Pygmi Woodpecker (Dendrocopos kizuki). Okajimas Folia Anat. Jpn., 86(1):31-5, 2009b.

Erdogan, S. \& Alan, A. Gross anatomical and scanning electron microscopic studies of the oropharyngeal cavity in the European magpie (Pica pica) and the common raven (Corvus corax). Microsc. Res. Tech., 75(3):37987, 2012.

Erdogan, S. \& Perez, W. Anatomical and scanning electron microscopic characteristics of the oropharyngeal cavity (tongue, palate and laryngeal entrance) in the southern lapwing (Charadriidae: Vanellus chilensis, Molina 1782). Acta Zool., 96(2):264-72, 2015.

Erdogan, S.; Sagsoz, H. \& Akbalik, M. E. Anatomical and histological structure of the tongue and histochemical characteristics of the lingual salivary glands in the Chukar partridge (Alectoris chukar, Gray 1830). Br. Poult. Sci., 53(3):307-15, 2012.

Guimarães, J. P.; de Britto Mari, R.; de Carvalho, H. S. \& Watanabe, I. S. Fine structure of the dorsal surface of ostrich's (Struthio camelus) tongue. Zoolog. Sci., 26(2):153-6, 2009.

Hayat, M. A. Principles and Techniques of Electron Microscopy: Biological Applications. $4^{\text {th }}$ ed. Cambridge, Cambridge University Press, 2000.

Homberger, D. G. \& Meyers, R. A. Morphology of the lingual apparatus of the domestic chicken, Gallus gallus, with special attention to the structure of the fasciae. Am. J. Anat., 186(3):217-57, 1989.

Igwebuike, U. M. \& Anagor, T. A. The morphology of the oropharynx and tongue of the muscovy duck (Cairina moschata). Vet. Arhiv., 83(6):68593, 2013.

Iwasaki, S. \& Kobayashi, K. Scanning and transmission electron microscopy studies on the lingual dorsal epithelium of chickens. Kaibogaku Zasshi, 61(2):83-96, 1986.

Iwasaki, S. Evolution of the structure and function of the vertebrate tongue. J. Anat., 201(1):1-13, 2002.

Iwasaki, S.; Asami, T. \& Chiba, A. Ultrastructural study of the keratinization of the dorsal epithelium of the tongue of Middendorff's bean goose, Anser fabalis middendorffii (Anseres, Antidae). Anat. Rec., 247(2):14963, 1997.

Jackowiak, H. \& Godynicki, S. Light and scanning electron microscopic study of the tongue in the white tailed eagle (Haliaeetus albicilla, Accipitridae, Aves). Ann. Anat., 187(3):251-9, 2005.
Jackowiak, H. \& Ludwig, M. Light and scanning electron microscopic study of the structure of the ostrich (Strutio camelus) tongue. Zoolog. Sci., 25(2): 188-94, 2008

Jackowiak, H.; Andrzejewski, W. \& Godynicki, S. Light and scanning electron microscopic study of the tongue in the cormorant Phalacrocorax carbo (Phalacrocoracidae, Aves). Zoolog. Sci., 23(2):161-7, 2006.

Jackowiak, H.; Skieresz-Szewczyk, K.; Godynicki, S.; Iwasaki, S. \& Meyer, W. Functional morphology of the tongue in the domestic goose (Anser anserf. domestica). Anat. Rec. (Hoboken), 294(9):1574-84, 2011.

Kadhim, K. K.; Mahdi, A. A. \& Al-Timmemi, H. Histomorphological and Histochemical Study on the Tongue of Black Francolin (Francolinus francolinus). Int. J. Anim. Vet. Adv., 6(6):156-61, 2014.

Kobayashi, K.; Kumakura, M.; Yoshimura, K.; Inatomi, M. \& Asami, T. Fine structure of the tongue and lingual papillae of the penguin. Arch. Histol. Cytol., 61(1):37-46, 1998.

Kooloos, J. G. M. A conveyer belt model for pecking in the mallard. Anas Platyrhynchos. J. Zool., 36:47-87, 1986.

Mahmoud, A. M.; Gadel-Rab, A. G. \& Shawki, N. A. Effect of different feeding behaviors on the roof of buccal cavity of two bird species. Egypt. J. Zool., 67:175-90, 2017.

Parchami, A. \& Dehkordi, R. A. Light and electron microscopic study of the tongue in the White-eared bulbul (Pycnonotus leucotis). Iran. J. Vet. Res., 14(1):9-14, 2013.

Parchami, A. \& Dehkordi, R. A. Lingual structure in the domestic pigeon (Columba livia domestica):a light and scanning electron microscopic study. World Appl. Sci. J., 12(9):1517-22, 2011.

Parchami, A.; Dehkordi, R. A. \& Bahadoran, S. Fine structure of the dorsal lingual epithelium of the common quail (Coturnix coturnix). World Appl. Sci. J., 10(10):1185-9, 2010.

Pasand, A.; Tadjalli, M. \&Mansouri, H. Microscopic study on the tongue of male Ostrich. Eur. J. Biol. Sci., 2(2):24-31, 2010.

Whittow, G. C. Sturkie's Avian Physiology. NewYork, Academic Press, 2000.

Zweers, G. The feeding system of the pigeon (Columba livia L.). Adv. Anat. Embryol. Cell Biol., 73:1-108, 1982.

Corresponding author:

Mohamed Abdo

Department of Anatomy and Embryology

Faculty of Veterinary Medicine

University of Sadat City

Sadat City 32897

EGYPT

E-mail: Mohamed.abdo@vet.usc.edu.eg

Received: 21-11-2020

Accepted: 01-12-2020 